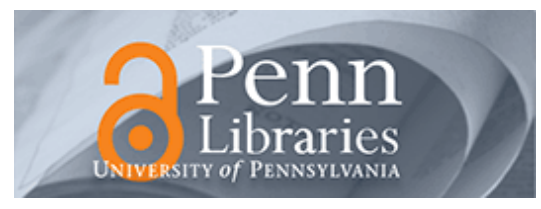

Manuscript Studies

\title{
Opening the Text in the Floreffe Bible (London, BL Add MS 17738): From Ways of Seeing to Ways of Touching
}

Dominic Marner

University of Guelph, dmarner@uoguelph.ca

Follow this and additional works at: https://repository.upenn.edu/mss_sims

Part of the Ancient, Medieval, Renaissance and Baroque Art and Architecture Commons, and the Medieval Studies Commons

\section{Recommended Citation}

Marner, Dominic () "Opening the Text in the Floreffe Bible (London, BL Add MS 17738): From Ways of Seeing to Ways of Touching," Manuscript Studies: Vol. 5 : Iss. 1 , Article 2.

Available at: https://repository.upenn.edu/mss_sims/vol5/iss1/2 


\title{
Opening the Text in the Floreffe Bible (London, BL Add MS 17738): From Ways of Seeing to Ways of Touching
}

\author{
Abstract \\ The Floreffe Bible is a two-volume bible now housed in the British Library (Add MSS 17737 and 17738). It \\ is a wonderful example of the complex relationship between text and image and between the \\ sophisticated interplay of exegesis and imagination. This study explores the interspatial, intertextual and \\ interactive aspects of a hole in the parchment on folio 180r/v. The hole both illustrates the text which \\ surrounds it and to provides a portal or aperture into the text below possibly providing the viewer/reader \\ with an opportunity to recreate a miracle of Christ by quite literally touching his garment. Likewise, once \\ the folio is turned another intertextual and interspatial opportunity is provided by the aperture. This \\ unusual situation demands considerable understanding of both the process of making the book and the \\ possibilities of interacting and reading the text and contributes to our understanding of the truly \\ sophisticated handling of text and image in the makers of the Floreffe Bible. This manuscript is infused \\ with typological and exegetical richness, inviting the reader the explore the opening in the text, not only \\ through sight but touch.
}

\section{Keywords}

Floreffe Bible, manuscripts, parchment, holes, touch, reading, miniatures, Durrow, exegesis, Manuscript Studies 
Marner: Opening the Text in the Floreffe Bible

\title{
MANUSCRIPT STUDIES \\ A Journal of the Schoenberg Institute for Manuscript Studies
}

\author{
VOLUME 5, NUMBER 1 \\ (Spring 2020) \\ Manuscript Studies (ISSN 2381-5329) is published semiannually \\ by the University of Pennsylvania Press
}

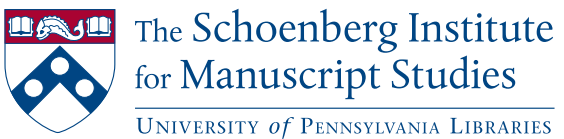




\section{MANUSCRIPT STUDIES}

VOLUME 5 , N U M B E R 1

(Spring 2020)

ISSN 2381-5329

Copyright (C) 2020 University of Pennsylvania Libraries

and University of Pennsylvania Press. All rights reserved.

Published by the University of Pennsylvania Press, 3905 Spruce Street, Philadelphia, PA 19104.

Printed in the U.S.A. on acid-free paper.

Manuscript Studies brings together scholarship from around the world and across disciplines related to the study of premodern manuscript books and documents, with a special emphasis on the role of digital technologies in advancing manuscript research. Articles for submission should be prepared according to the Chicago Manual of Style, $16^{\text {th }}$ edition, and follow the style guidelines found at http://mss.pennpress.org.

None of the contents of this journal may be reproduced without prior written consent of the University of Pennsylvania Press. Authorization to photocopy is granted by the University of Pennsylvania Press for libraries or other users registered with Copyright Clearance Center (CCC) Transaction Reporting Service, provided that all required fees are verified with CCC and paid directly to CCC, 222 Rosewood Drive, Danvers, MA 01923. This consent does not extend to other kinds of copying for general distribution, for advertising or promotional purposes, for creating new collective works, for database retrieval, or for resale.

\section{SUBSCRIPTION INFORMATION:}

Single issues: $\$ 30$

Print and online subscriptions: Individuals: \$40; Institutions: \$94; Full-time Students: \$30 International subscribers, please add $\$ 19$ per year for shipping.

Online-only subscriptions: Individuals: $\$ 32$; Institutions: $\$ 82$

Please direct all subscription orders, inquiries, requests for single issues, address changes, and other business communications to Penn Press Journals, 3905 Spruce Street, Philadelphia, PA 19104. Phone: 215-573-1295. Fax: 215-746-3636. Email: journals@pobox.upenn.edu. Prepayment is required. Orders may be charged to MasterCard, Visa, and American Express credit cards. Checks and money orders should be made payable to "University of Pennsylvania Press" and sent to the address printed directly above.

One-year subscriptions are valid January 1 through December 31. Subscriptions received after October 31 in any year become effective the following January 1 . Subscribers joining midyear receive immediately copies of all issues of Manuscript Studies already in print for that year.

Postmaster: send address changes to Penn Press Journals, 3905 Spruce Street, Philadelphia, PA 19104.

Visit Manuscript Studies on the web at mss.pennpress.org. 


\section{MANUSCRIPT STUDIES}

A Journal of the Schoenberg Institute for Manuscript Studies

VOLUME 5, N UMBER 1

Yemeni Manuscripts Online: Digitization in an Age

of War and Loss

NaNCY Um

Opening the Text in the Floreffe Bible (London, BL Add. MS

17738): From Ways of Seeing to Ways of Touching

DOMINIC MARNeR

Litterae florissae in English Manuscripts in the Late Twelfth/

Early Thirteenth Century

Sara Charles

The Durham Latin Prose "Brut" to 1347 with a Continuation

to 1348: A Nationalistic Chronicle of England and Its

Manuscripts

Trevor Russell Smith

A Brief Introduction to Seventeenth-Century Military

Manuscripts and Military Literacy

Lucian Staiano-Daniels

\section{Annotations}

How Many Glyphs and How Many Scribes? Digital

Paleography and the Voynich Manuscript

Lisa Fagin Davis

In the Orbit of the Sphere: Sacrobosco's De sphaera mundi in UPenn MS Codex 1881

Aylin Malcolm 
Manuscript Studies, Vol. 5 [], Iss. 1, Art. 2

iv | Journal for Manuscript Studies

\section{Reviews}

Erik Kwakkel and Rodney Thompson, eds. The European Book in the Twelfth Century.

JoANnA Fronska

Paul M. Love, Jr. Ibadi Muslims of North Africa: Manuscripts, Mobilization, and the Making of a Written Tradition.

Amanda Propst

Jeffrey F. Hamburger, Robert Suckale, and Gude SuckaleRedlefsen, eds. Painting the Page in the Age of Print: Central European Manuscript Illumination of the Fifteenth Century.

Gregory Clark

Erik Kwakkel, ed. Vernacular Manuscript Culture, 1000-1500.

Hannah Morcos

Gaudenz Freuler. The McCarthy Collection, Volume I:

Italian and Byzantine Miniatures.

BRyAN C. KeEne 


\title{
Opening the Text in the Floreffe Bible (London, BL Add. MS 17738): From Ways of Seeing to Ways of Touching
}

\author{
DOMINIC MARNER \\ University of Guelph
}

\begin{abstract}
he Floreffe Bible (British Library, Add. MSS 17737 and 17738) is a wonderful example of the complex relationship between

1 text and image and between the sophisticated interplay of exegesis and imagination. The manuscript was originally written and decorated at Floreffe, a Premonstratensian monastery founded in 1121 by St. Norbert, who was also the founder of the new monastic order. It has been dated variously to prior to 1139 and to circa 1170 and has been the subject of some scholarly interest by Walter Cahn, Jeffrey Hamburger, Anne-Marie Bouché, and others. ${ }^{1}$ The complex interplay between text and image, between read-
\end{abstract}

1 Walter Cahn, Romanesque Bible Illumination (Ithaca, NY: Cornell University Press, 1982), nos. 46, 198-99, 230, 265, pls. 154-55, 170-71; Jeffrey F. Hamburger, St. John the Divine: The Deified Evangelist in Medieval Art and Theology (Berkeley: University of California Press, 2002), 91-92, fig. 75, pl. 13; Anne-Marie Bouché, “The Spirit in the World: The Virtues of the Floreffe Bible Frontispiece: British Library, Add. MS 17738, ff. 3v-4r," in Virtue and Vice: Personifications in the Index of Christian Art, ed. Colum Hourihane (Princeton, NJ: Princeton University Press, 2000), 42-65; Anne-Marie Bouché, "Vox Imaginis: Anomaly and Enigma in Romanesque Art," in The Mind's Eye: Art and Theological Argument in the Middle Ages, ed. Jeffrey F. Hamburger and Anne-Marie Bouché (Princeton, NJ: Princeton University Press, 2006), 306-35; Werner Telesko, "The Picture of the Crucifixion in the Floreffe 
ing, meditation, and vision that was experienced by medieval readers, has been noted by contemporary monks such as Guido II (d. 1188/1192) and has been investigated in modern scholarship. For instance, Jeffrey Hamburger in his analysis of John's miniature in the Floreffe Bible sums up this interplay in the following way: "To view the illustrations with an eye to their meaning-determined as much by their diagrammatic structure as by extensive explanatory inscriptions - is to enter into an ongoing process of 'revelation' that the monastic readers of these books would have identified with the process of meditation and contemplative ascent." ${ }^{2}$ It is just this process of reading and ongoing revelation that will be explored in several folios of the second volume of this manuscript at a point in the text where, I will argue, a hole, or aperture in the parchment, acts as a space or opportunity for contemplative reading.

\section{Ways of Seeing: Images in the Floreffe Bible}

Before analyzing the relevant folios, it is important to recognize the sophisticated nature of the imagery in the Floreffe Bible, in particular, the miniatures in volume two. The second volume contains Job to Revelation in the Latin Vulgate and opens with two spectacular full-page miniatures (fols.

Bible (London, BL, Add. MS 17738, f. 187r),” British Library Journal 19 (1993): 105-9; Gretel Chapman, "The Bible of Floreffe: A Study of a Twelfth-Century Manuscript" (Ph.D. diss., University of Chicago, 1964); Anne-Marie Bouché, "The Floreffe Bible Frontispiece (London, British Library, Add. MS 17738, fol. 3v-4r) and Twelfth-Century Contemplative Theory" (Ph.D. diss., Columbia University, 1997). For a discussion of the dating of the manuscript, see Gretel Chapman, "The Bible of Floreffe: Redating a Romanesque Manuscript," Gesta 10 (1971): 49-62; Gretel Chapman, “The Floreffe Bible Revisited," Manuscripta 35 (1991): 96-137; Herbert Köllner, "Zur Datierung der Bibel von Floreffe. Bibelhanschriften als Geschichtsbücher?” Rhein und Maas 2 (Köln, 1973): 361-76. For a discussion of the Premonstratensian origins of the Floreffe Bible, see M. J. Stiennon, "La miniature dans le diocèse de Liège au XIe et XIIe siècles," in L'Art mosan, ed. P. Francastel (Paris: Armand Colin, 1953), 90-101; M. J. Stiennon, "Du lectionnaire de Saint-Trond aux Evangiles d'Averbode: Contribution à l'étude de la miniature mosane du XIIe siècle," Scriptorium 7 (1953): 37-50.

2 Hamburger, St. John the Divine, 83. For a discussion of Guido II, see Hamburger, St. John the Divine, 83 and 259 n. 6. 
Marner: Opening the Text in the Floreffe Bible

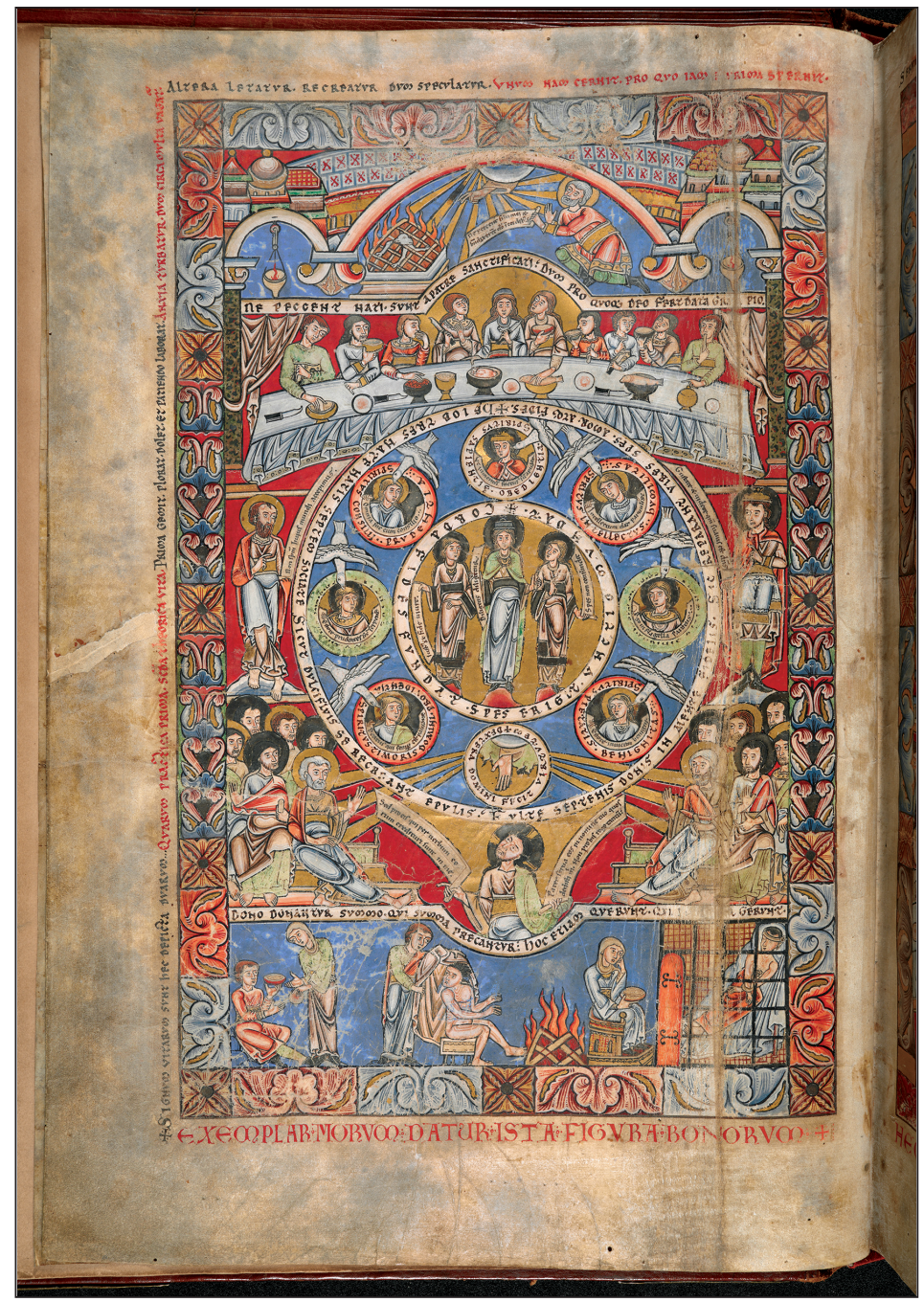

FIGURE 1. The Floreffe Bible, British Library Add. MS 17738, fol. 3v. Image (C) The British Library Board.

$3 \mathrm{v}-4 \mathrm{r}$ ) that focus on the allegorical understanding of the active and contemplative lives, the Virtues and Corporeal works of Mercy and the Transfiguration and Last Supper (fig. 1). As Katzenellenbogen and Cahn have argued, the first miniature is an exegesis on the Book of Job with scenes taken from Job, such as Job's family at a table for a feast in the upper zone 
(Job 1:4) and the sacrifice above made to absolve them from $\sin \left(\right.$ Job 1:5). ${ }^{3}$ The middle zone represents the seven Gifts of the Holy Spirit from Isaiah (Isaiah 11:2), which, according to Pope Gregory the Great's Moralia in Job, relates to the seven sons of Job, as represented above. ${ }^{4}$ This is enveloped by a larger circle within which the personifications of the virtues, Faith, Hope, and Charity, are represented. Just as the Gifts refer to the sons of Job, the three virtues refer to the daughters of Job, according to Gregory. ${ }^{5}$ The approach taken by Katzenellenbogen and Cahn was to read the images through the Moralia, and this approach tends to work well for most of the first miniature, but not necessarily for the lower section nor for the second miniature.

Anne Marie Bouche has critiqued this approach, pointing out that the image "begins with a well-known textual source, then conspicuously fails to adhere to it, and builds instead an entirely new exegetical structure on that patristic foundation." 6 Drawing upon the theology of Rupert of Deutz (ca. 1080-1129), a Benedictine from Liège, Bouché argues that the key to the image are the inscriptions written on banderoles held by figures that act as a textual bridge between the scenes at the top of the page and the unusual scenes in the lower register. ${ }^{7}$

The complex visual and textual exegesis of the first two miniatures with their sophisticated exploration of allegory and typology through Gregory's Moralia, and the works of Rupert of Duetz can also be found in the fascinating imagery prefacing the Gospels. It was Köllner who first pointed out that Rupert of Duetz had connected the symbols of the evangelists with the life of Christ: "Nam in evangelio Christus prius homo est per naturam,

3 A. Katzenellenbogen, Allegories of the Virtues and Vices in Medieval Art, from Early Christian Times to the Thirteenth Century (London, 1939; repr. Toronto, University of Toronto Press, 1989), 37-38; Cahn, Romanesque Bible, 198-99.

4 "Seven sons are born to us when, through the conception of right thinking, seven virtues are raised up in us by the Holy Spirit," quoted in Bouché, "The Spirit in the World," 46. See also Bouché, "Vox imagines," 306-17.

5 Bouché, "The Spirit in the World," 46-47.

6 Bouché, "The Spirit in the World," 43.

7 In particular, see the discussion regarding the relationship between Christus and unctus in Bouché, "The Spirit of the World," 47-51. 
Marner: Opening the Text in the Floreffe Bible

FIGURE 2. The Floreffe Bible, British Library Add. MS 17738, fol. 168r. Image (c) The British Library Board.

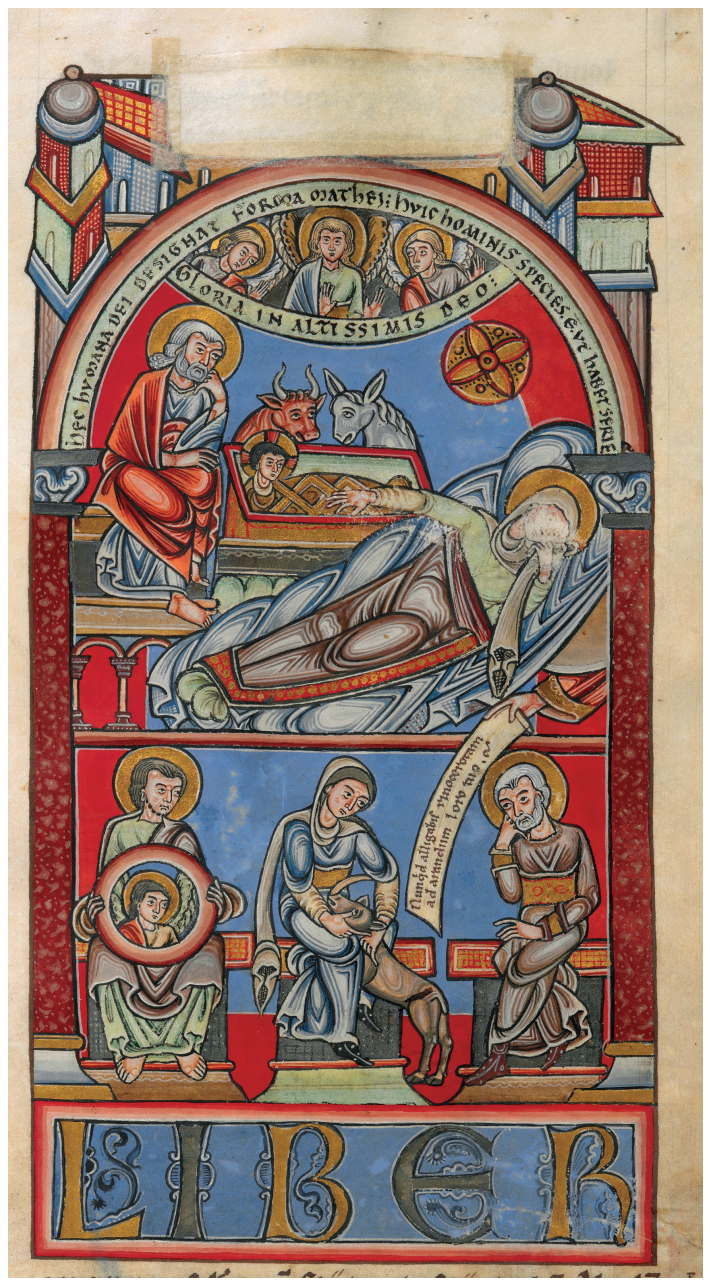

deinde vitulus per passionem, deinde leo per resurrectionem, deinde aquila per ascensionem.” ${ }^{8}$ Köllner suggested that the Nativity, Death, Resurrection, and Ascension of Christ, which form the themes of the images prefacing each Gospel, are inspired by the symbol of the Evangelist, a symbol that is also represented in each of the compositions. For instance, Matthew's Gospel (fig. 2) begins with a miniature in two registers, the upper one

8 Köllner, “Datierung,” 372. 
representing a scene of the Nativity; in the lower, according to Hamburger, Matthew holds a clipeus with his symbol of the winged man, while next to him is the Virgin holding a unicorn and Job holding a banderole: Numquid alligabis rbinocerota ad arandum loro tuo (Job 39:10). ${ }^{9}$ The unicorn, according to the Physiologus, is a symbol of Christ: "the spiritual unicorn, descended into the womb of the Virgin, and through her took on human flesh."10 The dual reference to the birth of Christ, first in the Nativity scene and second through the image of the unicorn and the text of the Pbysiologus, expands upon the typological and exegetical references of the imagery and reasserts Rupert of Duetz's contention that Matthew's symbol, the Man, is connected to his birth as a man.

Likewise, the Ascension scene that dominates John's miniature takes as its inspiration the symbol of John, the Eagle, an animal according to Duetz that is connected to the Ascension (fig. 3). The inscription around the frame of the miniature reasserts this relationship: "The four faces who are one man through his birth, ox through his death, lion through his resurrection, and bird through his return to heaven." 11 Further banderoles explore the ideas and imagery in relation to Ezekiel's prophetic vision, and as Hamburger points out, it was John who, in Revelation, "made plain the full meaning of Ezekiel's vision," something that Adam of St. Victor (d. between 1172 and 1192) explored in his commentary. ${ }^{12}$

Werner Telesko explores the theology of Rupert of Duetz in order to uncover the exegetical framework of the miniature prefacing Luke's Gospel (fig. 4). Like the other Gospel miniatures, the scene responds to Duetz's connection between the animal, in this case vitulus, and the associated concept, passionem, or Crucifixion. The upper part of the image is a representation of the Crucifixion, complete with the lance piercing Christ's right side,

9 Hamburger, St. John the Divine, 89. For the inscriptions on some of the banderoles in the Floreffe Bible, see Arwed Arnulf, Versus ad picturas: Studien zur Titulusdicbtung als Quellengattung der Kunstgeschichte von der Antike bis zum Hocbmittelalter (Munich: Deutscher Kunstverlag, 1997), 245-48.

10 Quoted in Cahn, Romanesque Bible, 210.

11 Quoted in Hamburger, St. Jobn the Divine, 85.

12 Hamburger, St. John the Divine, 86. 


\section{Marner: Opening the Text in the Floreffe Bible}

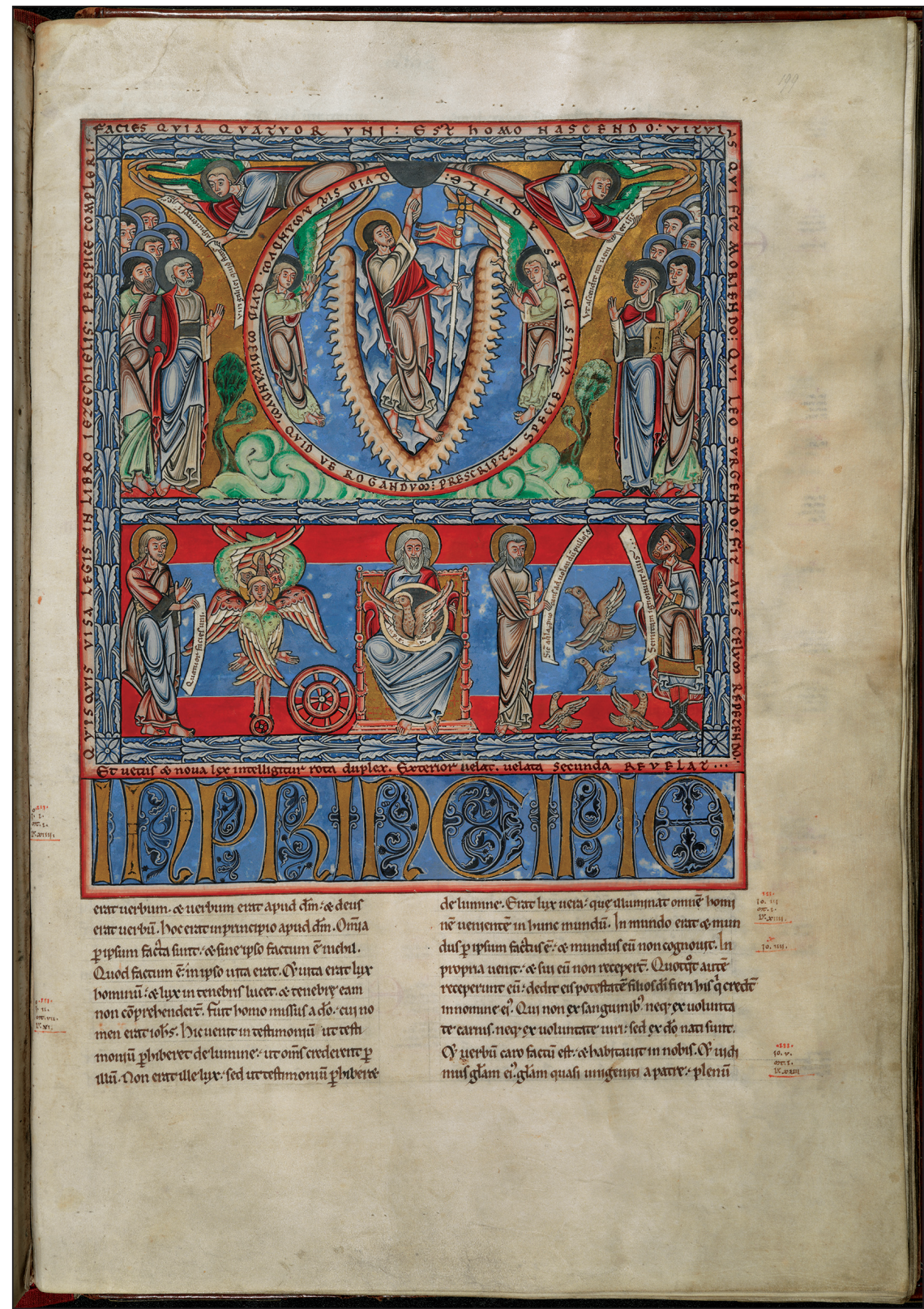

FIGU RE 3. The Floreffe Bible, British Library Add. MS 17738, fol. 199r. Image (C) The British Library Board. 
Manuscript Studies, Vol. 5 [], Iss. 1, Art. 2

52 | Journal for Manuscript Studies

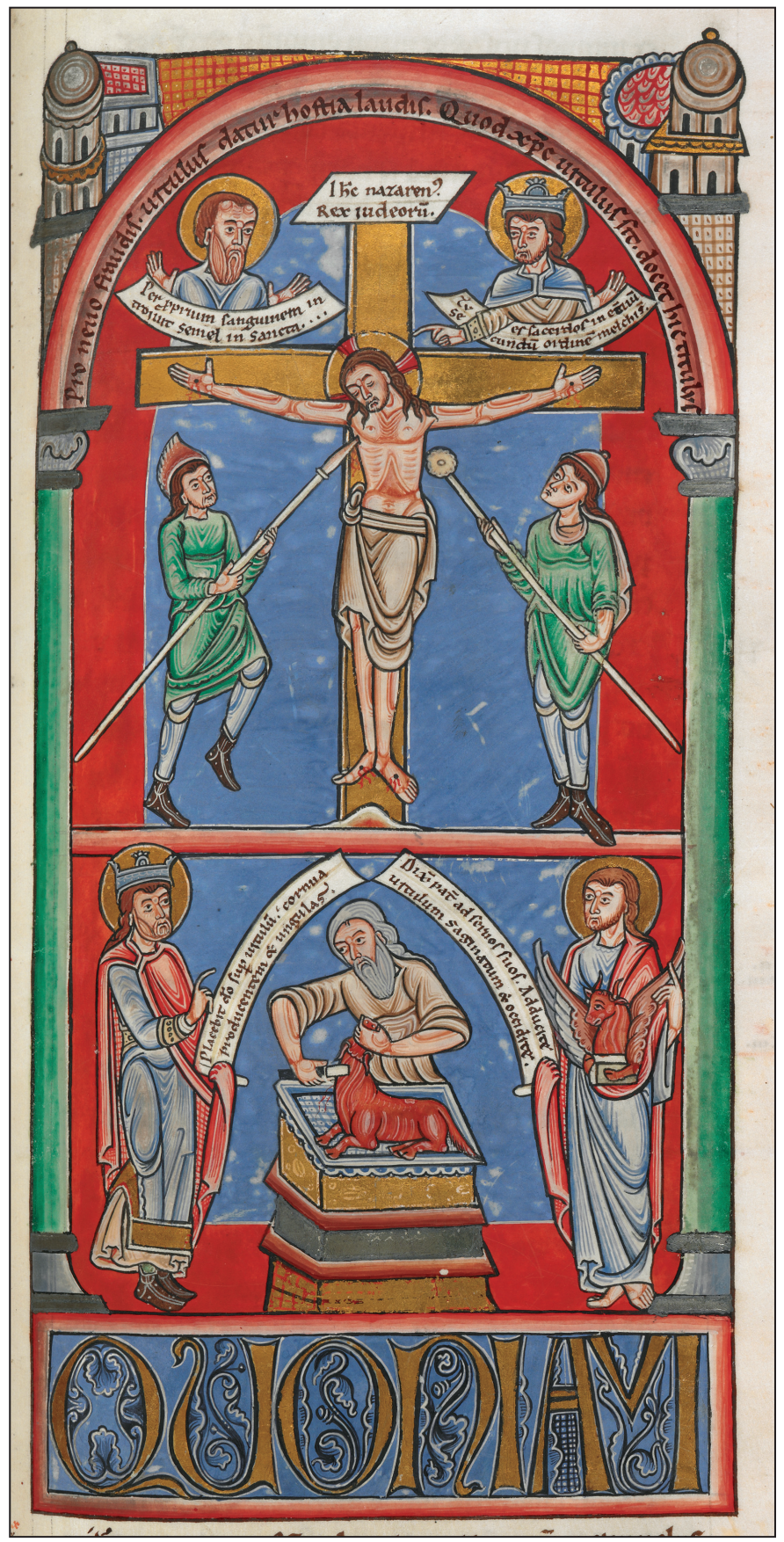

FIGURE 4. The Floreffe Bible, British Library Add. MS 17738, fol. 187r. Image (C) The British Library Board. 
an act mirrored below with the knife inserted into the neck of the fatted sacrificial ox of the Old Testament. Like the images of Matthew and John, Luke holds his winged symbol in the lower register, while his banderole reads, "And the father said to his servants. Bring hither the fatted calf, and kill it" (Luke 15:23). ${ }^{13}$ The typological associations are made explicit between the sacrifice of the vitulus in the Old Testament and the Crucifixion of Christ in the New and, furthermore, this connection is made explicit visually by representing in both registers the act of piercing and, indeed, the wound itself. Telesko refers to Deutz, who considered Christ as the vitulus, a word that is echoed in the banderoles held by the figures and the inscription around the frame, and a word that Telesko claims is a tertium comparationis, a term he argues is "the essential foundation for the make-up of the miniature's content." ${ }^{14}$ Vitulus is the word that brings together both image and text, a kind of exegetical hinge upon which text and image make sense. Furthermore, this exegetical emphasis and exploration through a single word reflects an important practice in early scholastic theology in which a single term might be used to bridge the Old and New Testaments, a technique used and employed by the makers of this image.

The term vitulus also brings together another important connection made by Deutz, the link between the Eucharist and the Crucifixion. Telesko maintains that the quotation from Luke (15:22 ff.) and the associated parable of the prodigal son are key to understanding this relationship. Just like the prodigal son, Adam was driven out of paradise and, as such, the archetypal "lost son" was redeemed "only when Christ becomes 'food' for the lost son who has been accepted back into the community, as the victim slaughtered for the feast (bostia), do forgiveness and a return to God become possible." ${ }^{15}$ Telesko posits that the Old Testament sacrificial calf is typologically linked to Christ's self-sacrifice, while in the image the textual allusion to the prodigal son brings the textual and visual ideas together. According to Duetz, the beginnings of mankind are redeemed in the Eucharist, and the

13 Dixit pater ad servos suos. Adducite vitulum saginatum et occidite.

14 Telesko, "The Crucifixion," 108.

15 Telesko, "The Crucifixion," 107. 
tertium comparationis of this image, or the hinge upon which this theology is based, is the term vitulus. ${ }^{16}$

Finally, just as Matthew's and John's Gospels begin with images associated with the Physiologus, so too does Mark's (fig. 5). Like the other Gospel miniatures, rather than simply depicting the evangelist with his symbol, the decorator of the manuscript decided to use associated meanings of the symbol as an inspiration to represent exegetically linked aspects of the Gospel narrative. For instance, prefacing Mark's Gospel is his symbol, the lion, in the lower register, who has just breathed life onto the whelps. According to the Bestiary, the whelps are born dead, and after three days, when the lion breathes upon them, they come to life. The symbol of Mark, therefore, is notionally associated with the idea of Resurrection. As a result, the images in the upper two registers correspond to this idea of Resurrection by showing, at the top, the three women at the empty tomb (Mark 16:1-8), and in the middle, the three Marys' encounter with Christ after his Resurrection (Matthew 28:9). This middle register combines a scene as it is described in Matthew with that of Mark's version. The encounter in Matthew's Gospel includes Christ's greeting, "Avete," or "Hail," while the description in Mark includes the touching of Christ's foot by the Magdalen, which functions as a counter to the Noli me tangere event as described in John's Gospel (John 20:17).

\section{Ways of Touching the Word}

These images are fascinating. The complex iconography is exegetically informed by both early and contemporary theologians, and clearly indicates that the makers and readers of this book had access to and knowledge of

16 For the Eucharist, see Telesko, "The Crucifixion," 108. For a discussion on the development of biblical distinctiones (a related exegetical tool), see Mary A. Rouse and Richard H. Rouse, Authentic Witnesses: Approaches to Medieval Texts and Manuscripts (Notre Dame, IN: University of Notre Dame Press, 1991), 222-36, and Richard H. Rouse and Mary A. Rouse, "Biblical Distinctiones in the Thirteenth Century," Archives d'bistoire doctrinale et littéraire du moyen âge 41 (1975, for 1974): 27-37. 


\section{Marner: Opening the Text in the Floreffe Bible}

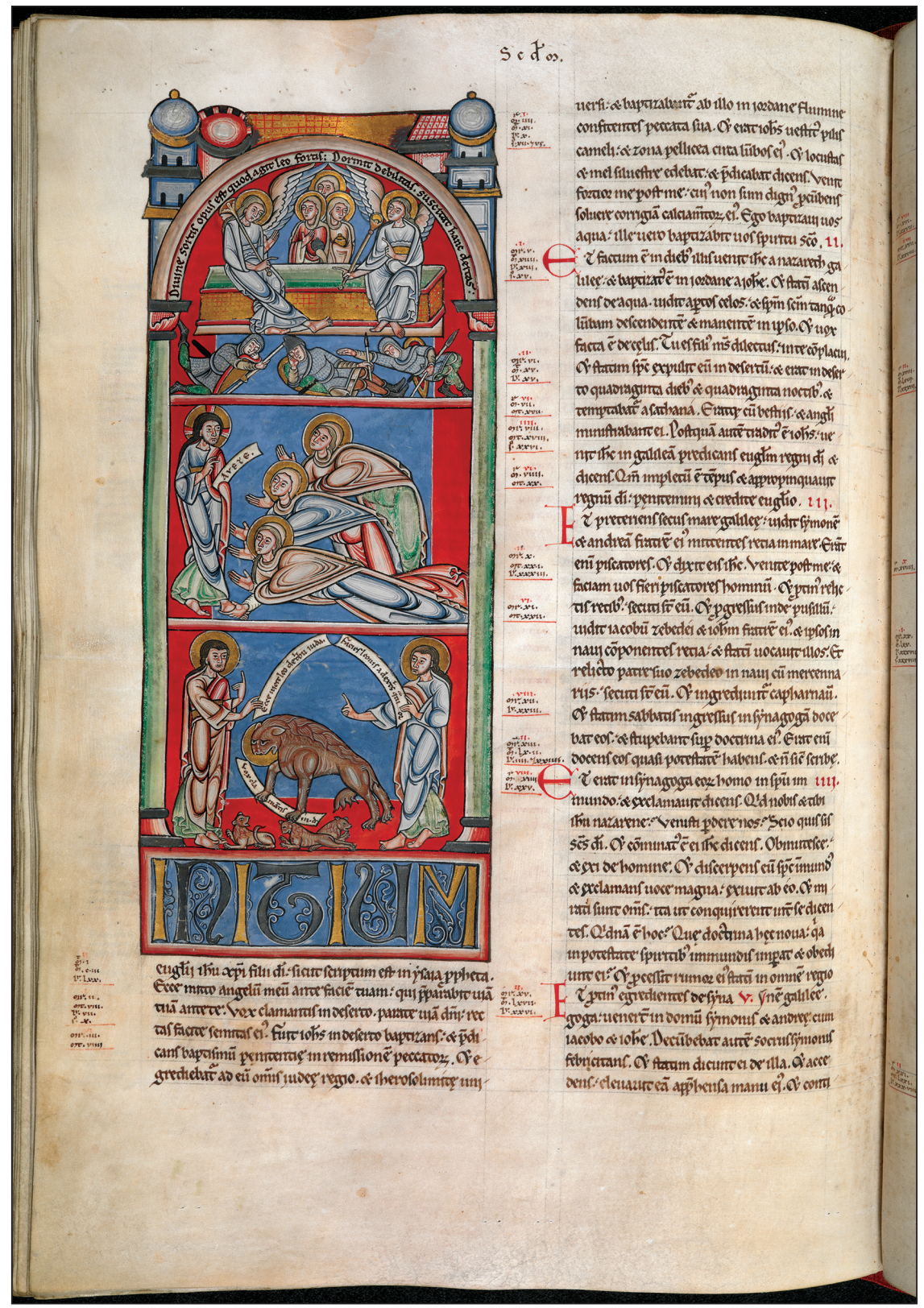

FIGURE 5. The Floreffe Bible, British Library Add. MS 17738, fol. 179v. Image (C) The British Library Board. 
these exegetical traditions. ${ }^{17}$ Because of the large format $(48 \times 33.5 \mathrm{~cm}$ pages and $37.5 \times 24.5 \mathrm{~cm}$ text space), the Floreffe Bible can be described as a "giant Bible" typical of the Romanesque period. As Christopher de Hamel notes, these large Bibles were often given as gifts to churches or monasteries frequently by bishops and, as such, were not only expressions of the word of God, but the status of those giving and receiving this Word. De Hamel cautions not to assume that because these books were large, they were used only for public reading in the refectory and the chapel during services, and not for private use. ${ }^{18}$ Indeed, the rather complex imagery in the these giant Bibles and, in particular, the Floreffe Bible, would seem to demand considerable knowledge on the part of the reader to appreciate the iconography.

This sophisticated and meditative approach to the imagery provides the context for understanding another aspect of the book: a significant defect or hole in the parchment $(2.5 \mathrm{~cm} \times 1.0 \mathrm{~cm})$ that occurs on the page opening of the image to Mark (fol. 180r; fig. 6). The hole is striking and arresting because of its symmetry, shaped carefully as if it had been purposefully cut out. In comparison, other parchment holes tend to be uneven in their appearance and more rounded in form. They are sometimes left as is, or sometimes sewn or patched.

In terms of defective parchment, there are forty-nine holes ranging in size from small holes (less than $1 \mathrm{~cm}$ ) to larger ones (usually circular-shaped ones with a diameter of $2.5 \mathrm{~cm}$ ) that have been patched. ${ }^{19}$ These holes appear in both the outer and lower margins as well as the text columns. Further defective parchment occurs where the lower margin of a folio is missing (fols. 22r, 54r, 106r, 190r, 196r, 226r, 259r, 247r). Where this occurs, the lower margin

17 For a discussion of the education of the Premonstratensians and their ties to the Parisian scholarship of the Victorines, see Anne-Marie Bouché, "Vox imaginis," 315-17.

18 Christopher De Hamel, The Book: A History of the Bible (London: Phaidon, 2001), 64-91, especially 73. See also Larry M. Ayres, "The Italian Giant Bibles: Aspects of Their Touronian Ancestry and Early History," in The Early Medieval Bible: Its Production, Decoration and Use, ed. Richard Gameson (Cambridge: Cambridge University Press, 1994), 125-54.

19 Patched holes: fols. 5v, 6r, 8r, 12r, 13r, 15r, 25r, 30r, 31r, 32r, 39r, 53r, 56r (tear repair sewn), 58r, 66r, 68r, 71r, 85r, 86r, 90r, 93r, 94r (tear repair sewn), 98r, 101r, 105r, 115r, 128r, 136r, 138r, 142r, 144r, 154r, 168r, 177r, 201r, 203r, 211r, 215r, 217r, 219r, 225r, 244r, 246r, 250r (tear repair sewn), 255r. 


\section{Marner: Opening the Text in the Floreffe Bible}

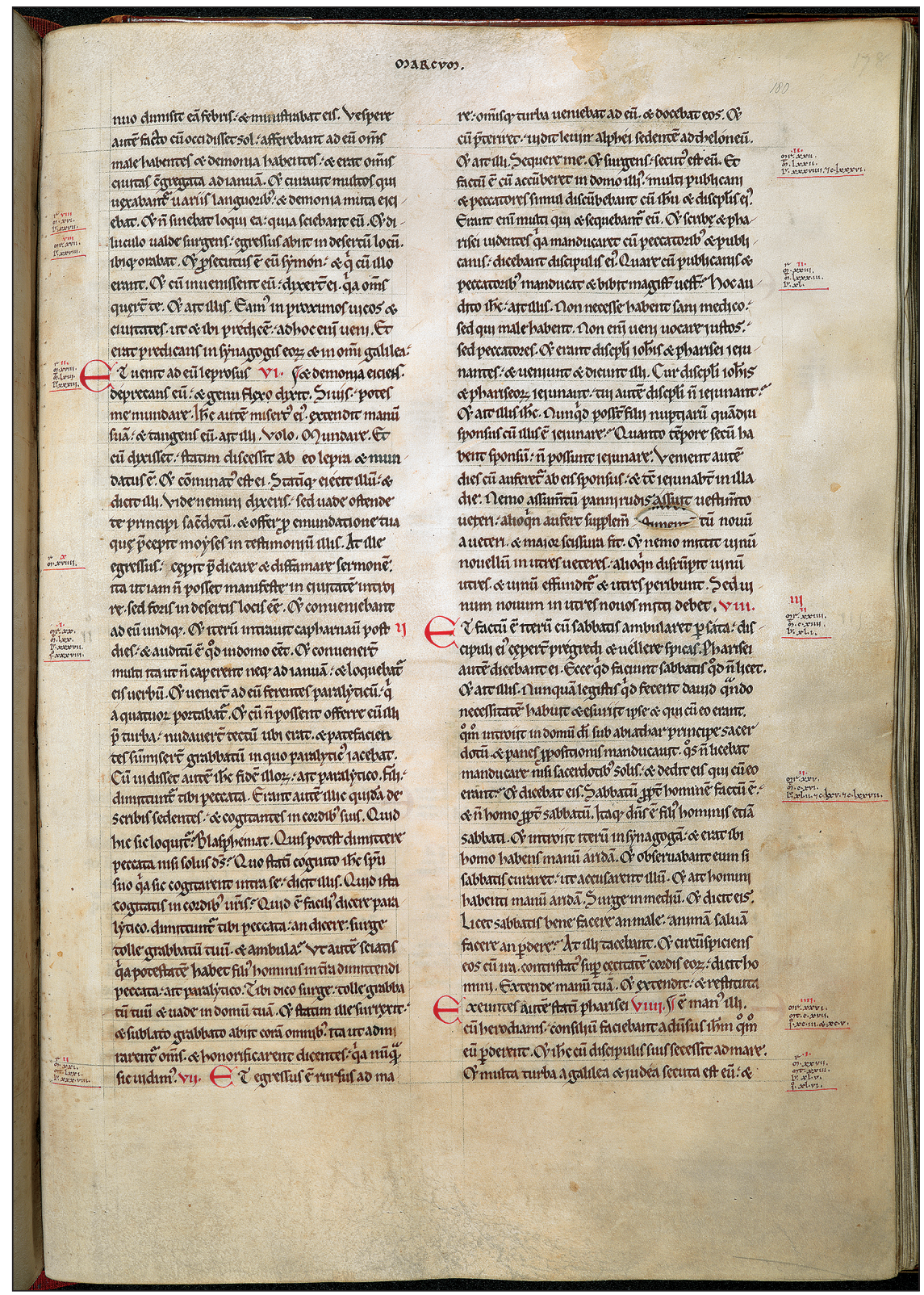

FIGU RE 6. The Floreffe Bible, British Library Add. MS 17738, fol. 180r. Image (C) The British Library Board. 
has received a strip of parchment that extends across the page so the folios look exactly like the others. In the Floreffe Bible, it would seem that the patching of a hole or strip was the established practice.

Having said that, there are a few exceptions in the text columns. There are six very small holes (less than $0.5 \mathrm{~cm}$ ) in the text space that have not been patched and two small tears that have been sewn. There are two other holes that have not been patched and are of comparable size to the hole on folio 180r. However, they are of uneven shape, more like a natural hole found elsewhere in other manuscripts, and they do not seem to have any textual or interactive aspects to them. Based upon the analysis of the holes themselves, it appears that the majority of the holes, whether they were marginal or in text columns, were patched systematically.

Close examination of the hole on folio 180r reveals important aspects of its production (fig. 7). First, the page ruling above the hole stops abruptly at the hole and does not continue after the hole. The ruling below runs continuously, as do the other lines on the page. This indicates that the hole, or perhaps a tear, was there prior to ruling. Second, the hyphenation of the word supplementum also indicates that the hole was there prior to writing the text, and the fact that no text is missing from the Gospel verse indicates the same conclusion. Conversely, the destruction of part of the head stroke of the letter $t$ in supplementum indicates that the letter was present prior to

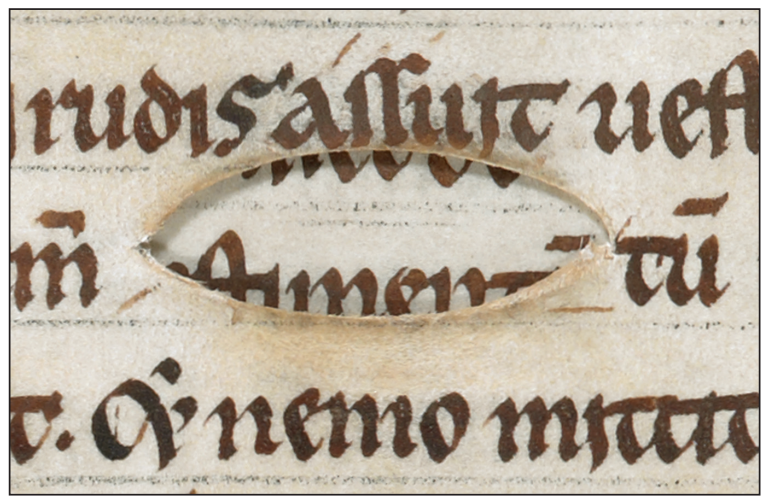

FIGURE 7. Detail, The Floreffe Bible, British Library Add.

MS 17738, fol. 180r. Image (C) The British Library Board. 
the hole. Finally, there looks to be a smudge just under the lower part of the hole, and a descending minim can be seen from the folio underneath, which may indicate that there is some wear at that point.

This situation can be explained if there was a hole or tear in the parchment at the time the page was being ruled. This tear was then avoided by the scribe in writing the text, and then finally, for some reason, the hole was extended, making it perhaps more symmetrical and larger, thereby accidentally damaging elements of the letter $t$. In other words, there were two stages to the evolution of this hole. The text at this point is from Mark 2:21: "No man seweth a piece of raw cloth to [patch] an old garment: otherwise the new piecing taketh away from the old, and there is made a greater rent." The verb to patch, assuit, is significantly directly above the hole, with the next word being vestimento, cloak or garment. This verse is a meditation on whether or not it is worthwhile patching an old garment, because if you do, it may simply fall apart in any case. It is a rather apt verse for the scribe who may have had a potential decision to patch, or not patch, the piece of parchment in front of him. It is possible that the scribe might have delighted in this scribal/textual coincidence, and instead of patching the hole, he tidied up the original tear as a way of highlighting this unusual, perhaps even miraculous, textual coincidence.

Before analyzing this evidence, I would like to point out another feature of the hole, a rather obvious one: the reader can see through the hole to the next folio, in this case, folio 181r. In fact, the word that lies on the other side is vestimentum or garment, tantalizingly echoing the word above the hole. The word garment can be glimpsed partially through the hole, somewhat hidden, and under the smudged area. This vestimentum is from the miracle of the woman with the issue of blood in Mark 5:27-32 (fig. 8):

And a woman who was under an issue of blood twelve years, and had suffered many things from many physicians; and had spent all that she had, and was nothing the better, but rather worse, when she had heard of Jesus, came in the crowd behind him, and touched his garment. For she said: If I shall touch but his garment, I shall be whole. And forthwith the fountain of her blood was dried up, 
Manuscript Studies, Vol. 5 [], Iss. 1, Art. 2

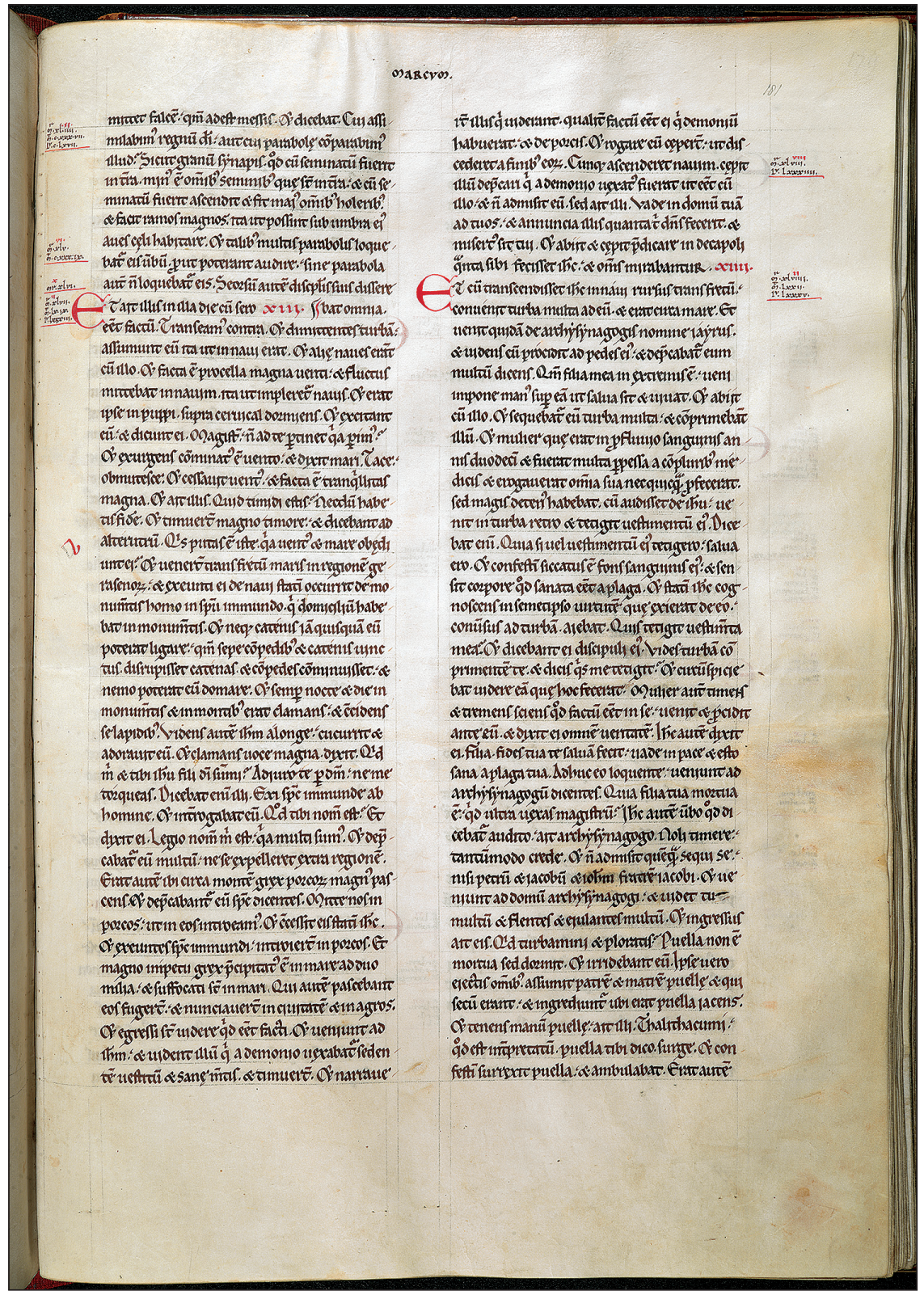

FIGURE 8. The Floreffe Bible, British Library Add. MS 17738, fol. 181r. Image (C) The British Library Board. 
and she felt in her body that she was healed of the evil. And immediately Jesus knowing in himself the virtue that had proceeded from him, turning to the multitude, said: Who hath touched my garments?

This miracle has been characterized as a stolen miracle in that the woman with the hemorrhage secretly came through a crowd behind Christ and touched his garment, tetigit vestimentum, knowing that she would be cured. ${ }^{20}$ Christ sensed that something happened, then turned and asked who touched him. It is my contention that the aperture provided the reader with an opportunity to touch the cloak of Christ just as the hemorrhaging woman had, hidden and from behind, only this time the page itself functioned to hide the identity of the reader, who carefully placed his (or her) finger on the vestimentum of Christ and, in so doing repeatedly, smudged the area around the hole, causing the parchment to become thinner, thereby exposing the descending minum of one of the letters below (see fig. 7). ${ }^{21}$ The hole invited the reader to reenact this Gospel miracle through touch. If this understanding is correct, this would have fascinating implications for the interactive aspects of the book in terms of touching, and the layering of text, images, and ideas throughout the manuscript.

The miracle of the hemorrhaging woman is also unusual because it is embedded in a larger miracle, the resurrection of the daughter of Jairus. As Christ goes to the house of Jairus, he is interrupted by the events of the hemorrhaging woman. After she is cured, he continues to the house, where

20 Barbara Baert, ed., The Woman with the Blood Flow (Mark 5:24-34) (Leuven: Peeters, 2014), 1-34. Liesbet Kusters, "Touching and Not Touching Jesus: The Haemorrhaging Woman in the Narrative and Visual Culture of the Early Middle Ages (Fourth-Eleventh Century)," in Barbara Baert, The Woman, 229-85. For a discussion of seeing through a hole in the parchment and touching a hole in a thirteenth-century French anthology, see Nancy Vine Durling, "Birthmarks and Bookmarks: The Example of a Thirteenth-Century French Anthology,” Exemplaria 16, no. 1 (2004): 73-94, especially 92.

21 Another part of the manuscript that appears to be damaged due to repeated touching or veneration is the face of the Virgin in the Nativity scene prefacing Matthew's Gospel. It is the only face to have been damaged in the entire manuscript and may indicate a special veneration for the Virgin by (Premonstratensian) readers. 
he discovers the girl has died and therefore resurrects her, saying, "Talitha, cumi, which means, Maiden, I say to thee, rise up" (Mark 5:41). The miracle of the hemorrhaging woman and its relationship to this resurrection miracle has received considerable scholarly attention in particular by Barbara Baert, who has written extensively on the early medieval visual responses to this miracle. ${ }^{22}$ In a particularly evocative and poetic passage that discusses Carlo Ginzburg's thoughts on the miracle of the woman with the issue of blood, she says,

In his essay "À distance," Carlo Ginzberg [sic] has inimitably discussed how the introduction of the Haemorrhoissa into early Christian art cannot be separated from a fascination for what he calls the punctum: l'instant decisive. In the interspace of image and word one finds "moments of suction." The moment that Christ's clothes are touched is joined together with the moment of healing (fons sanguinis siccatus est) and with the moment that Jesus feels a power (dynamis, virtus) flowing from him and He looks back. In the condensation of energy around these verses ... the opening towards the image presents itself. The text tears open and the visual moment escapes: le point décisif.23

Although this description has nothing to do with the Floreffe Bible, the particularly evocative ideas of a punctum - l'instant decicif and le point décisif, "moments of suction" and the tearing of the text as the visual moment escapes-encapsulate beautifully the interactive moment when the reader touches the partially hidden cloak of Christ through the hole.

Before going further, I would like to pause briefly to reflect on the visual representations of the hemorrhaging woman in early medieval art. An early representation of the event comes from the third-century catacomb of Saints Peter and Marcellinus (fig. 9). The scene shows the woman extending her hand toward Christ's garment, touching his hem while Christ turns

22 Baert, The Woman, 6-23.

23 Barbara Baert, Liesbet Kusters, and Emma Sidgwick, "An Issue of Blood: The Healing of the Woman with the Haemorrhage (Mark 5.24-34; Luke 8.42-48; Matthew 9.19-22) in Early Medieval Visual Culture," Journal of Religion and Health 51 (2012): 667-68. 
Marner: Opening the Text in the Floreffe Bible

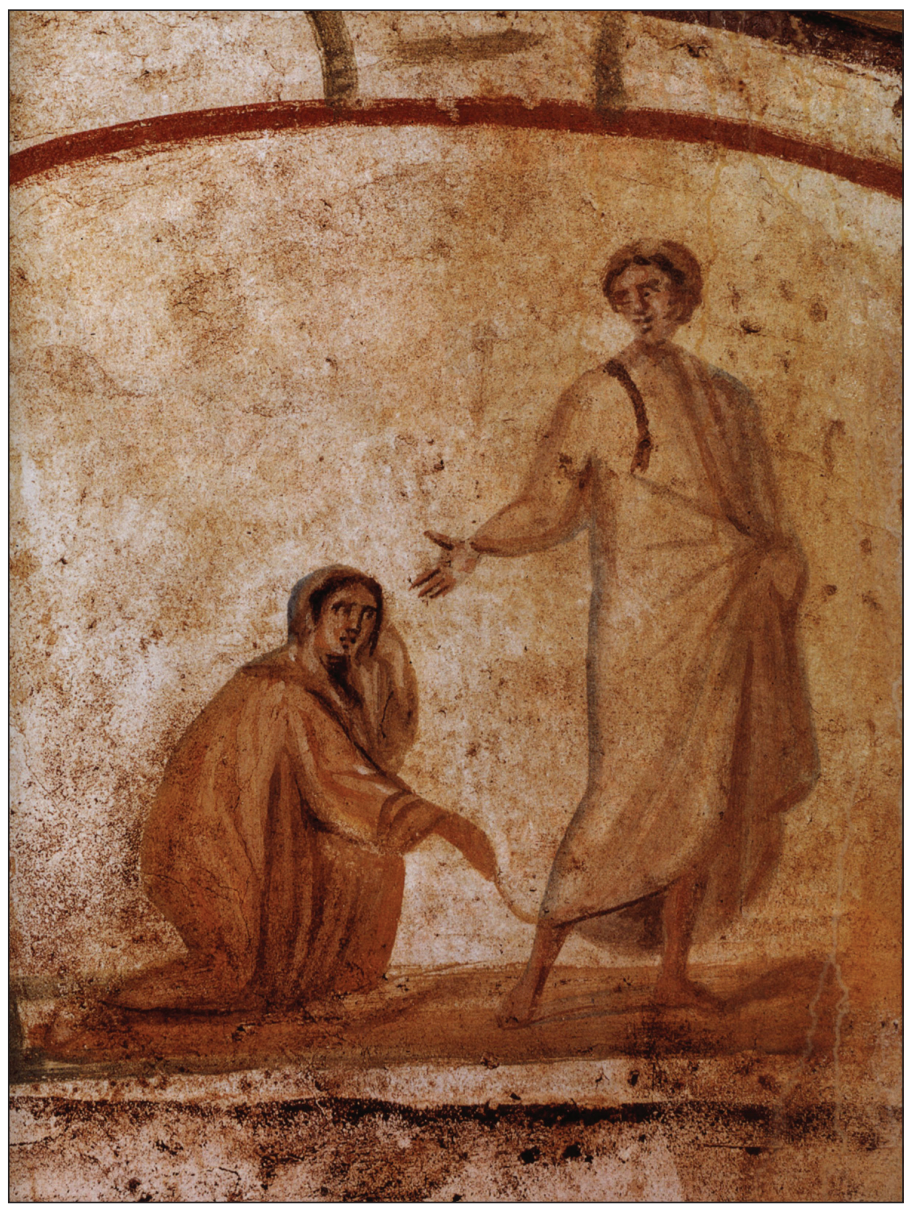

FIGURE 9. Jesus and Haemorrhoissa, wall painting in the catacomb of Peter and Marcellinus, burial room 65, Rome.

and extends his hand in blessing. The scene conflates both moments of touching and blessing, what Ginzburg described as a decisive instant and Baert described as a "moment of suction." This reaching, touching, and turning becomes part of the iconography of the scene throughout the early medieval period and includes a kneeling or prostrate figure of the woman at Christ's feet. As Liesbet Kusters has remarked, "The touch of the Hemorrhaging woman is not a straightforward touch, but through her approaching Jesus from behind a touch that overcomes Him, takes Him by surprise, 
Manuscript Studies, Vol. 5 [], Iss. 1, Art. 2

64 | Journal for Manuscript Studies

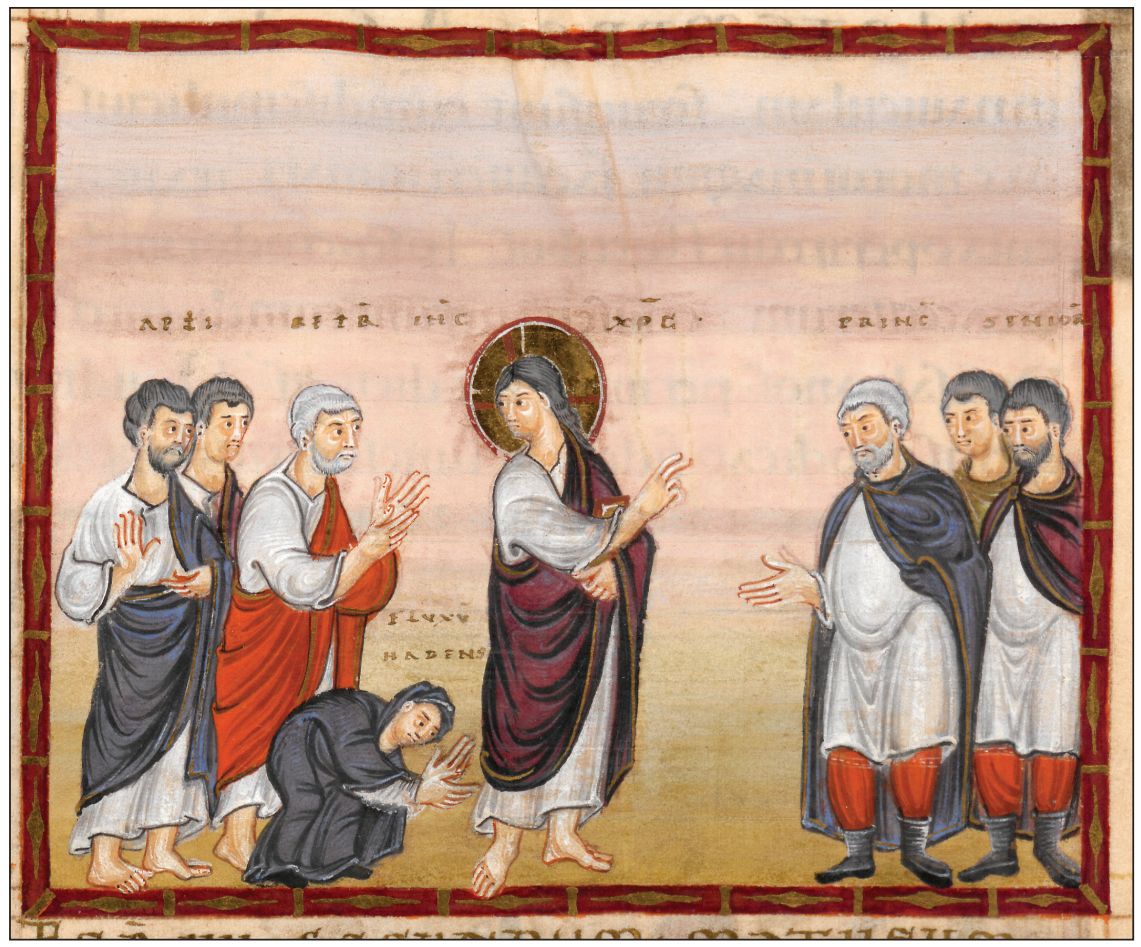

FIGU RE 10. Healing of Haemorrhoissa, Codex Egberti, Trier, Stadtarchiv/Stadtbibliothek Trier, MS 24, fol. 24v.

happens in a flash, unexpected and ephemeral." ${ }^{24}$ The iconographic convention of showing the woman crawling or kneeling or reaching toward Christ's garment or cloak and Christ's body turning toward her made it hard to distinguish this event from other visual representations of Christ's interactions with women such as the Canaanite woman, the crippled woman, Martha, and the Noli me tangere motif. ${ }^{25}$ This ambiguity is what may have caused the maker of the image in the Codex Egberti (Trier, Stadtbibliothek, MS 24, fol. 24v) to label the woman Flux babens to distinguish her from other women Christ encountered (fig. 10). ${ }^{26}$ Likewise, the visual narrative is embellished in the Gospel Book of Otto III (Munich, Bayerische Staatsbib-

24 Kusters, "Touching and Not Touching," 229.

25 Kusters, "Touching and Not Touching," 234-35.

26 Kusters, "Touching and Not Touching," 247-49. 


\section{Marner: Opening the Text in the Floreffe Bible}

liothek, Clm 4453, fol. 44r) in which the healing of the hemorrhaging woman is combined with the larger story of the resurrection of Jairus's daughter in which it is textually embedded (fig. 11). Here, however, the gesture of the touching woman is visually echoed in the gesture of Christ

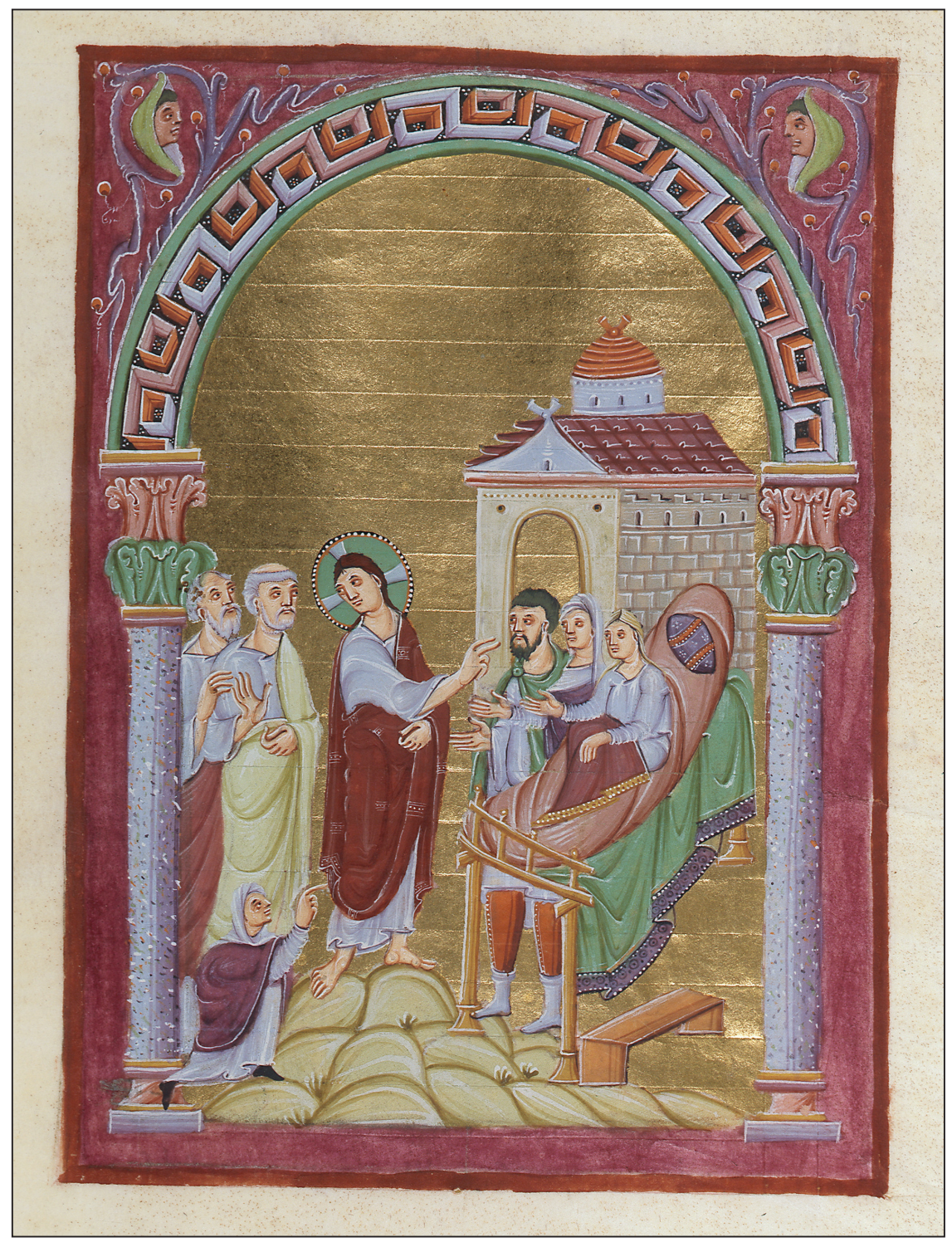

FIGURE 11. Healing of the Haemorrhoisa and the daughter of Jairus, Gospel Book of Otto III, Munich, Bayerische Staatsbibliothek, Clm 4453, fol. 44r. 
toward the risen child, making the contrast between the two events even more striking: "a stolen touch and a given touch." ${ }^{27}$ The parallel gestures and stories reflect, among other things, the symbolic relationship between a woman suffering from a hemorrhage for twelve years and a twelve-yearold girl who has been resurrected. The flow of blood from the woman can be linked typologically to the blood of Christ, the fons sanguinis, and ultimately to the Resurrection and the Eucharist.

To summarize: I believe that there was a tear in the parchment that was then extended by the scribe in response to the text around it, which asks whether it is worthwhile to patch a cloak. This opened the space to the word beneath, vestimentum, which acted as an invitation to the reader to touch the cloak of Christ, secretly and from behind, just as the woman with the hemorrhage had done in the miracle story, and this stolen touch led to a smudge above the word and on the edge of the hole. Just as the miracle story of the issue of blood interrupts and breaks the larger miracle of the resurrected child, so too does the hole in the parchment literally break the text, interrupting the written word on the page and moving the reader to another interspatial and intertextual moment. The miracle of the woman is also embedded in the larger narrative that speaks to both the notion of resurrection and of Eucharist, the blood of Christ, the font of blood, and the vested body of Christ. These complex interspatial, inter-exegetical, and intersensorial aspects are truly remarkable and must have been understood as almost miraculous by the reader.

But what happens when the reader turns the page? A hole after all has two sides, two opportunities for looking through it, or perhaps reading through it and around it. Once the page is turned, the aperture invites, not necessarily tactility, a physical touch, but a "scopic" touch (fig. 12). The aperture becomes an eye, a window into the image beneath and before, a frame, an arresting visual moment highlighting the scene beneath, and in this case a glimpse of the cloak of Mary (and part of the halo), but this time the painted vestimentum of Mary. This hole, this window, this eye acts as a reminder of the scene in which Mary Magdalen touches Christ, touches the

27 Kusters, "Touching and Not Touching," 253. 


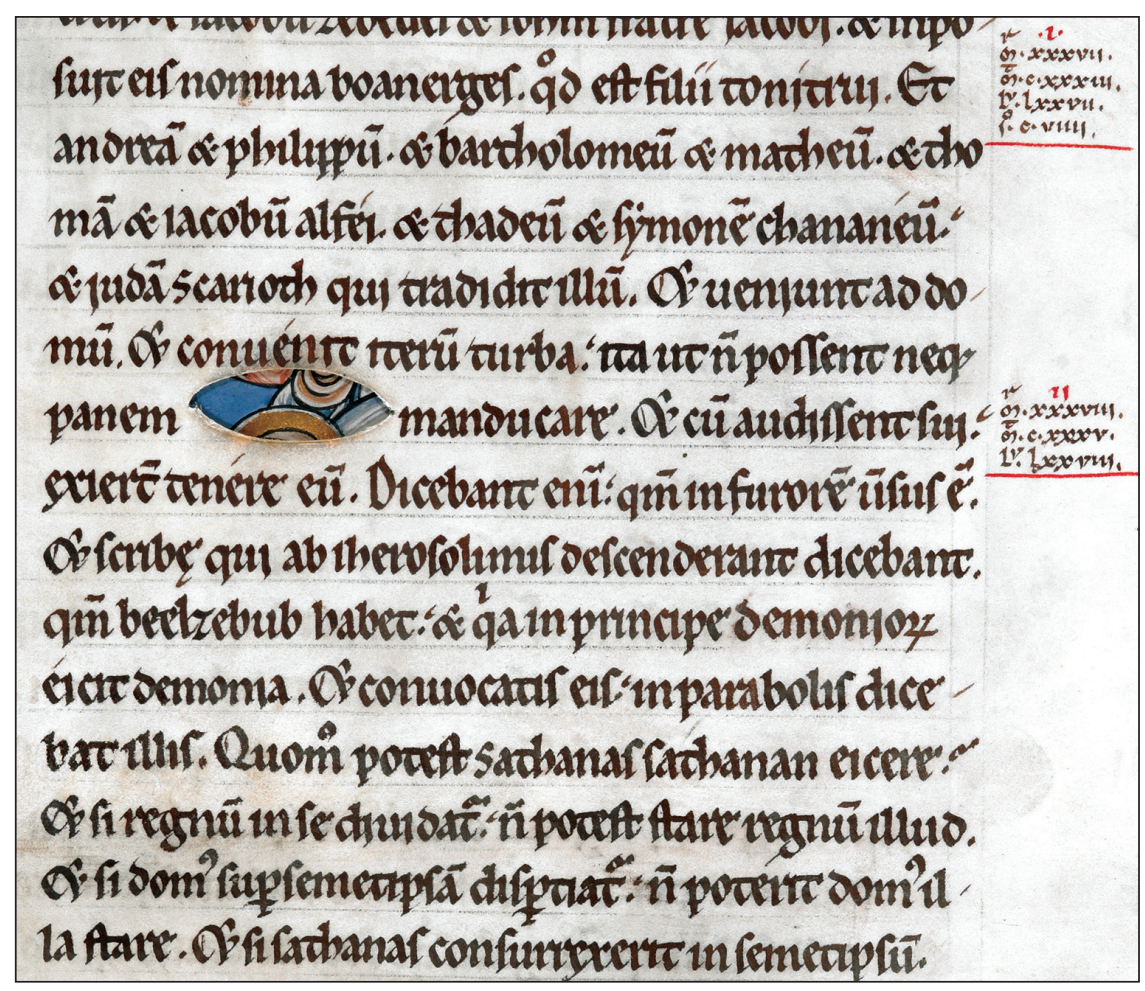

FIGURE 12. The Floreffe Bible, British Library Add. MS 17738, fol. 180v. Image (C) The British Library Board.

body of Christ, an act that contrasts with the hemorrhaging woman's physical touch of the cloak of Christ, but an act that replicates, through a scopic touch, the reader's act of touching. The typological associations developed in the story of the woman with an issue of blood and the larger story of the resurrected child are visually reinforced in the image of the three women witnessing the resurrected Christ, through sight and touch (see fig. 5). Furthermore, the visual conventions used in this image echo those of the visual conventions used to describe the miracle of the hemorrhaging woman, conventions that presumably would have been appreciated by the maker and reader of this manuscript. Through the aperture and by turning the page, the reader moves from an interactive participator of the miracle of the hemorrhaging woman to a witness of the resurrected Christ. Furthermore, as 
the reader turns the page, the words that frame the eye, or perhaps mouth, are panem manducare, to eat bread (fig. 12). The Eucharistic reference cannot be more obvious and, indeed, the word panem itself overlays the image of the body of Christ underneath while the word manducare covers the stomach of Mary. Just as the word vestimento on the previous page echoed and overlaid the vestimentum of Christ touched by the woman, so here the words echo the images on the previous folio. Just as the miracle of the hemorrhaging woman can be linked to the Eucharistic blood of Christ, the fons sanguinis, so here the body of Christ is textually and visually linked with the panem, the bread of the Eucharist. ${ }^{28}$

How might this interspatial, intertextual, and interactive work be understood by the makers and readers in the abbey at Floreffe? First, the monastery of Floreffe was founded in 1121, approximately fifty years prior to the making of this manuscript. It was the second foundation of the Premonstratensian order, which, like the Cistercians, was a reforming order of the Benedictine order. ${ }^{29}$ It was founded by St. Norbert, who wrote the formulary for their profession. Understandably, St. Norbert adopted certain aspects of the Benedictine customs, such as the singing of the Divine Office. However, he added a unique custom that was a special devotion to the Holy Eucharist, with the rubric of the first chapter of the Statuta, De tremendo altaris Sacramento. This seems to indicate that devotion to the Holy Eucharist as a sacrifice and sacrament would have played an important role in the monastic community of Floreffe. ${ }^{30}$ This emphasis on the Holy Eucharist is presumably connected to a miracle that happened when St. Norbert himself said Mass at the abbey at Floreffe upon its consecration where he discovered blood on the paten at the altar, an event witnessed by a deacon, Rodolph. ${ }^{31}$

28 For a discussion of the Haemorrhoissa and the Eucharist, see Kusters, "Touching and Not Touching," 258-71.

29 François Petit, O. Praem, Spirituality of the Premonstratensians: The Twelfth and Thirteenth Centuries, trans. Victor Szczurek, ed. with a foreword by Carol Neel (Collegeville, MN: Order of Saint Benedict, 2011).

30 For the centrality of the Eucharistic devotion, see Petit, Spirituality of the Premonstratensians, 266-77.

31 The event was described in Vita B of St. Norbert and was probably written between 1155 and 1164-in other words, just prior to the making of the Floreffe Bible. It was presumably 
This miraculous occurrence ascribed to the mythical originary moment of the founding of the monastery with its associations of fons sanguinis must not have escaped a Premonstratensian monk as he touched, witnessed, and meditated upon this marvelous aperture while turning of the pages of this book.

These associations would quite literally or indexically be linked once the reader turns the page and continues reading. Having turned the page once more, the aperture would disappear from view but would function as a physical portal through which the cloak of Christ (the word vestimentum) on folio $181 \mathrm{r}$ would touch the cloak of Mary (the visual image) on folio $179 \mathrm{v}$ as she, in turn, touches Christ. Having just read at the bottom of folio 181r that the twelve-year-old girl was resurrected by Christ, the first sentence the reader encounters when turning the page is "and they were beside themselves with wonder" (fol. 181v). Indeed, although this sentiment relates textually to the resurrected child, one might imagine that those who had just engaged in the interspatial and intertextual aspects of the previous folios through the hole, the eye, and the mouth of the parchment would have experienced equal wonder and amazement.

\section{Marking and Making Openings}

My suggestion is that a possible tear in the parchment presented an opportunity for the scribe or reader to engage in an intertextual/interspatial understanding of the text and image, a complex situation that could be understood as parallel to the complex exegetical references embedded in the images themselves. However, given the inventive and exegetically sophisticated imagery, it is crucial to ask if there is any evidence to suggest that this hole or this situation in the Floreffe Bible was intentionally planned from the outset. Rather than simply dismissing the hole and its placement as a

known to the order at Floreffe prior to this date, but would have had a more immediate impact for the makers and readers of the Floreffe Bible in ca. 1170. W. M. Grauwem, "Norbert et les débuts de l'abbaye de Floreffe," in Analecta Praemonstratensia LI (1975), especially "IV. La légende eucharistique de Floreffe," 20-23. 
coincidence, and possibly irrelevant, I will investigate the extent to which the makers of the manuscript may have purposefully created a situation that enabled an interactive and meditative situation to take place. We can, of course, never know the extent of the intentionality of the makers, but we can weigh the evidence for and against such an intention and explore the potential interactive possibilities afforded to the reader. To assess this possibility, it is necessary to consider the format of the page, the spacing of the letters, the frequency of abbreviation marks, and the construction of the pages by the page rulers.

If the hole on folio 180r was planned, one might expect that the script itself would show signs of either compression or expansion as the scribe wrote the text. In order to line up the text and hole perfectly at the word vestimentum, for instance, it may have been necessary to make adjustments in spacing. ${ }^{32}$ However, there seems to be no obvious attempt over the folios of expansion or compression. Below the hole on folio 180r, starting the next section of text beginning with the red letter $E$, the text looks slightly compressed, but nothing drastic or sustained. Likewise, in terms of spacing, the column widths are relatively even $(\mathrm{ca} .11 \mathrm{~cm})$ and are comparable to column widths elsewhere in the manuscript. Another way in which the scribe might line up text is to increase or decrease the number of abbreviations. If one includes the ampersand as an abbreviation and counts the numbers per column (forty-five lines, leaving out the last line), the following numbers occur: fols. 179v col. b: 168; 180r col. a: 161; 180r col. b: 182; 180v col. a: 182; 180v col b: 209; 181r col a: 190; 181r col. b: 181; 182v col. a: 169 . These numbers indicate a slight increase in the number of abbreviations to the point of the hole on folio 180r, and perhaps more significantly, more abbreviations on folios $180 \mathrm{v}$ and $181 \mathrm{r}$, leading to the word vestimentum on folio 181r col. b. However, despite this increase (and subsequent decrease) in abbreviations, their statistical value is limited. It seems that if the scribe is

32 Although there is no evidence of such a mark in Harley 2253, Durling has argued that there is evidence of scribal care taken to line up texts with holes. Durling, "Harley 2253," 272-74. 
lining up the text to place the word vestimentum underneath the hole, it is well thought out and very few obvious adjustments were made. ${ }^{33}$

There are, however, two clues that might suggest that the scribe was lining up text, image, and aperture over these folios. Above the word vestimentum on folio $181 \mathrm{r}$ is a small distinct line written with the page ruler's pencil (see figs. 7 and 8). This line is directly above the letters "men" of vestimentum and clearly visible through the hole on the previous folio and is slightly thinner than the ruling. Given the page ruling directly above it, it gives the appearance of a double line precisely at this spot. It could have been made by an absentminded reader at a later date. Or it could be a remnant of the page layout preparation, perhaps created if one page were on top of the other while the page ruler prepared the page and accidentally ruled through the hole. However, if this were the case, why would the line be thinner? It may have been introduced as an afterthought, perhaps as an odd version of an abbreviation mark for those looking through the hole, but if so it would probably not have been written with the page ruler's pencil but, instead, the ink of the scribe, like all of the other abbreviation marks. In any case, if it was a version of an abbreviation mark, it would not make sense once the page was turned and the reader came to that word on the page. Furthermore, the addition of a plummet line above a word does not occur anywhere else in the manuscript. It only occurs at this one spot precisely at the point where the critical word vestimentum is written, and in addition, it lines up precisely with the hole on the previous folio. Since it was made using the page ruler's pencil, it was probably made at the same stage as the page rulings - that is, prior to the writing of the script, and in conjunction with the planning of the folios. Despite not knowing precisely how the line was produced, it is clearly unique and perhaps indicated to the scribe an important position, the position of the word vestimentum in relation to the hole itself.

The second piece of possible evidence is equally subtle and occurs with the planning of the image on the previous folio. Just as the hole on folio

33 In terms of its organization, it should be noted that there is evidence of at least ten faint preparatory drawings in the margins where some of the decorated initials occur. 
180r reveals the word vestimentum on folio 181r, the other side of the hole on $180 \mathrm{v}$ reveals the visual vestimentum of one of the three Marys' touching Christ in the image on $179 \mathrm{v}$. It is important to note that in planning these folios, the image size determines precisely where the Gospel text will start on the first column, a factor that is crucial to consider if the scribe is attempting to position text several folios later. In this case, the image itself is larger than the images prefacing both Matthew and Luke, but not John. John's image has a larger, square format, appropriate given John's prominence among the Gospel writers, while Matthew's and Luke's are similarly planned within the width of the first column. ${ }^{34}$ The larger size of Mark's image results in the text beginning further down the page and may have been a factor if the scribe was trying to line up the word vestimentum on folio $181 \mathrm{r}$ with the hole on folio 180r. What is significant in coordinating holes, text, and image is that the total image height is 32 centimeters, and the part of the image that is visible through the hole is precisely halfway down the image-that is, 16 centimeters. This could be a coincidence, but given the mark possibly indicating the placement of the word vestimentum on folio 181 r, it is possible that the image itself was considered in the planning process, and that the vestimentum of Mary was positioned with the hole.

\section{Touching the Vulnus Christi}

It was well established in the Middle Ages that the parchment of a manuscript, literally the skin of the codex, was understood in certain contexts to echo metaphorically the body of Christ, a metaphor that might provide yet another "reading" and another "touching" opportunity. This relationship between parchment and Christ was noted by Hrabanus Maurus in the ninth century and was explored iconographically in medieval book-making and exegetically in medieval commentary, receiving particular attention in the devotional texts and prayers of the thirteenth and fourteenth centuries. ${ }^{35} \mathrm{In}$

34 Matthew: $24.5 \times 12.5 \mathrm{~cm}$; Mark: $32 \times 13.5 \mathrm{~cm}$; Luke: $28 \times 13.5 \mathrm{~cm}$; John: $29 \times 25 \mathrm{~cm}$.

35 Hrabanus Maurus, Opusculum de Passione Domini, chap. 3-4, Patrologia Latina 112.14261427, quoted in Durling, "Harley 2253," 291; Vladimir Gurewich, “Observations on the Iconog- 
a rare illustration of the Raising of the Cross in the fourteenth-century Neville of Hornby Hours (London, British Library, MS Egerton 2781, fol. 156r), Kathryn Smith sensitively observes that the scene of erecting the Cross was placed directly below the text that reads "and with a great nail they attached his feet to the Cross very firmly so that his body was stretched as tight upon the Cross as parchment on a frame." ${ }^{36}$ Furthermore, Smith points out that the left hand of Christ extends into the text and touches the word parchemine, making the relationship between Christ and parchment explicit. ${ }^{37}$ As a result, Smith concludes that "Christ's body is like parchment, or like the very book the reader is holding, and thus, contemplating the body of Christ Crucified is like the penitential act of devotional reading itself." 38 This metaphorical understanding of parchment has fascinating implications for tears or holes in parchment, especially in manuscripts with devotional or Gospel texts associated with the Passion cycle or ones that have typological associations with death, blood, and resurrection. Extending this metaphor, Nancy Vine Durling has argued that the five holes in the parchment in the Passion group of poems in the fourteenth-century manuscript London, British Library, MS Harley 2253, were deliberately chosen and placed near the Passion poems by the maker to reflect the five wounds of Christ and that the scribe was "exploiting the wounded skin of the parchment as a visual analogue of Christ's wounds." ${ }^{39}$ Just as the parchment

raphy of the Wound in Christ's Side, with Special Reference to Its Position," Journal of the Warburg and Courtauld Institutes 20, no. 3/4 (1957): 358-62; A. A. Barb, "The Wound in Christ's Side," Journal of the Warburg and Courtauld Institutes 34 (1971): 320-21; Flora Lewis, "The Wound in Christ's Side and the Instruments of the Passion: Gendered Experience and Response," Women and the Book: Assessing the Visual Evidence, ed. Jane H. M. Taylor and Lesley Smith (Toronto: University of Toronto Press, 1997), 204-29. For a discussion of parchment as an index of a body, see Elina Gertsman, "Phantoms of Emptiness: The Space of the Imaginary in Late Medieval Art," Art History (2018): 804.

36 Kathryn A. Smith, "The Neville of Hornby Hours and the Design of Literate Devotion," Art Bulletin 81, no. 1 (1999): 72-92 at 81.

37 Smith, "The Neville of Hornby Hours," 81.

38 Smith, "The Neville of Hornby Hours," 82.

39 Nancy Vine Durling, "British Library MS Harley 2253: A New Reading of the Passion Lyrics in their Manuscript Context,” Viator 40, no. 1 (2009): 271-307 at 280. 
is a metaphor for the body of Christ, so the tears in the parchment are a metaphor of Christ's vulnus.

Although Durling is considering a manuscript of devotional literature of the fourteenth century and exploring the notion of the use of parchment holes as analogs of Christ's wounds, it is important to consider whether other such vulnus references exist in tears and holes of earlier parchment, or whether this was a phenomenon peculiar to fourteenth-century devotional books. In this regard, I would like to point out a previously unrecognized vulnus in the parchment of the seventh-century Book of Durrow (Dublin, Trinity College, MS 57, fol. 121r). ${ }^{40}$ The hole in the parchment occurs at Mark 15:25 and splits the word crucifixe/runt: "And it was the third hour, and they crucified him" (fig. 13). I would suggest that the hole in the parchment was deliberately chosen so that it would divide the word "crucified" and, like the holes in Harley 2253, evoked in the reader contemplation of the wound of Christ at the moment of Crucifixion. Furthermore, the hole has a peculiar added tear at the top that seems to point to the line directly above and precisely in between the words vestimentum eius: "And crucifying him, they divided bis garments" (Mark 15:24). I would suggest that the added tear at the top, which literally divides the text on the page, also draws the reader's attention to the division of Christ's garments, a tear echoed a few lines later (Mark 15:38) where, upon the death of Christ, "the veil of the temple was rent in two, from the top to the bottom." Incredibly, at this point in the text another hole lies directly below the word velum and splits the word summon. It is as if the division of Christ's garments and the division of the veil in the Temple are being linked typologically through the

40 Rachel Moss, The Book of Durrow Official Guide (London: Thames \& Hudson, 2018), 34; Bernard Meehan, The Book of Durrow: A Medieval Masterpiece at Trinity College Dublin (Dublin: Town House, 1996); George Henderson, From Durrow to Kells: The Insular GospelBooks, 650-850 (London: Thames \& Hudson, 1987). For a discussion of the production of parchment and the potential reasons for holes in manuscript parchment due to insects, infestation, disease, or the quality of calf skin, see Kathleen Ryan, "Holes and Flaws in Medieval Irish Manuscripts," Peritia 6-7 (1987-88): 243-64; Roger Powell, "The Book of Kells, the Book of Durrow: Comments on the Vellum, Makeup and Other Aspects," Scriptorium 10 (1956): 3-21. 


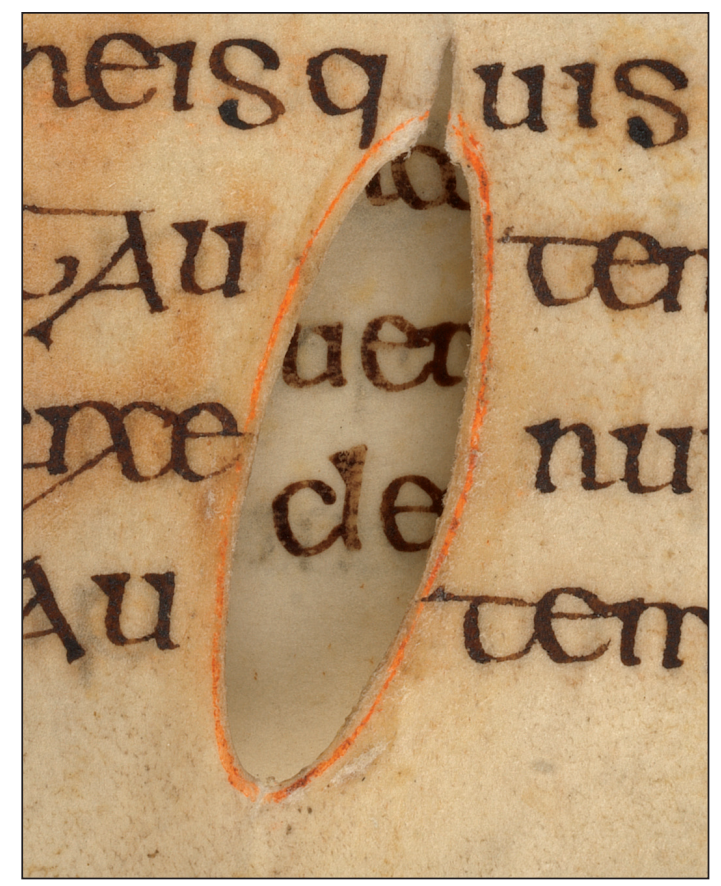

FIGURE 13. Book of Durrow, Dublin Trinity College MS 57, fol. 121r. Board of Trinity College, University of Dublin.

marker of the hole. ${ }^{41}$ Finally, as if to emphasize the idea of the vulnus, the scribe who placed small red dots around the larger letters beginning the section on folio 121r, significantly, encircled the wound with a red line as if to draw attention to the blood of the wound (fig. 13). Although there are both patched and unpatched holes throughout the parchment of the Book of Durrow, this is the only hole that is encircled by a red line. To my knowledge, this is the earliest example of using defective parchment to

41 The introduction of a vulnus in the Book of Durrow may reflect a larger interest in the cult of the True Cross and the Passion in early medieval Ireland. For a discussion of the relationship between the cult of the True Cross and the cross-carpet pages of Durrow, see Martin Werner, "The Cross-Carpet Page in the Book of Durrow: The Cult of the True Cross, Adomnan and Iona," Art Bulletin 72, no. 2 (1990): 174-223. 
metaphorically allude to the wound of Christ. This example extends the tradition to the early medieval period and expands the practice from devotional books to Gospel books. Indeed, it may indicate that the use of holes as analogs to Christ's wounds, or as markers, for linked texts of ideas, was far more widespread than has been previously demonstrated. ${ }^{42}$

Another important point that Durling makes has to do with touch. Durling notes that in the refrain of the second poem in Harley 2253, mention is made of "Saint Thomas," which she suggests might be the Apostle Thomas, or the Doubting Thomas, who examined Christ's wounds. This evocation may have led the reader in Harley 2253 to not only read the text and contemplate the holes (wounds), but "even touch them as part of the meditative reading and active remembering." ${ }^{43}$ This act of touching would have placed the reader in the position of Thomas, reminding the reader of Thomas's doubt and the faith necessary to believe in Christ's Resurrection. This event or act of touching by Thomas was represented in many medieval illustrations, from the early Middle Ages onward, and even had a significant impact on medieval dramatic performances. ${ }^{44}$ If the hole in Floreffe on folio $180 \mathrm{r}$ can be considered a vulnus, then the act of touching the hole by the reader to activate or recreate the miracle of blood on folio 181r may also have additional implications associated with the touch of Thomas. For the reader, touching Christ's garment and touching Christ's wound would be one encounter bound together in the tactile and exegetical interface of the hole. Furthermore, the act of Thomas's touch and its implied reference to the blood of Christ would be linked typologically to the issue of blood on the next folio, and by implication to the larger miracle of Resurrection in which the miracle of the blood story is situated. Actuated by the reader's touch, blood, death, and resurrection are exegetically implicated at the hole,

42 The hole itself may be understood as analogous to the process of reading and understanding, or a kind of pause for meditation and a reminder that understanding can only happen through the layered reading of the text. It is also an empty space through which the reader negotiates meaning. Elina Gertsman points out that "because all emptiness bears tracesvisual, cognitive, material-it often functions as a footprint of its makers and beholders, of their viewing practices, of their sensorium." Gertsman, "Phantoms of Emptiness," 804.

43 Durling, "Harley 2253," 281.

44 Glenn W. Most, Doubting Thomas (Cambridge, MA: Harvard University Press, 2009). 
the tear, and the wound. This implication is extended once the page is turned, as the aperture reveals the vestment of one of the Marys who touches Christ. The act of touch is repeated and, significantly, Thomas's touch and the touch of Mary are the only times in the Gospels that Christ is touched post-resurrection and signify recognition. In the Floreffe Bible, these moments of touch have been brought together though the hole, allowing the reader to explore in rather remarkable ways the ideas of blood, death, and resurrection, by touching and seeing.

\section{Ways of Seeing and Ways of Touching}

The interplay between text and image and between exegesis and the sacred word in medieval manuscripts has long been recognized. In this respect, the Floreffe Bible is not an exception. What makes the Floreffe Bible exceptional is the complicated and sophisticated handling of the imagery that has been recognized by Cahn, Hamburger, Bouché, Telesko, and others. In addition to these previous studies, the textual and visual interplay of a hole in the parchment on folio 180r must be introduced. Defective parchment, whether it be a tear, strip, or a hole and whether it is patched, unpatched, or sewn, is ubiquitous in medieval manuscripts. The process of making parchment, and the chemical, genetic, and environmental factors determining the quality of parchment, has been thoroughly examined by previous scholars and is the necessary first step in understanding the making of a medieval book. However, a hole is not necessarily just a hole, and furthermore, defective parchment is not necessarily simply indicative of an inferior manuscript. This study opens the door a little further to considering defective parchment as having an important role in reading or viewing the text and suggests that is not simply in devotional literature of the fourteenth century that this kind of interpretation occurs but in a twelfth-century Bible and a seventh-century Gospel book. This practice may, indeed, have been more pervasive throughout the medieval period and compels us to consider the use of defective parchment more sensitively. A hole is a gap, a space, a void, or an emptiness through which the reader might explore the sacred text and by extension, God. In the Floreffe Bible, it functions as a 
"moment of suction," a point decisive, a pause for the reader to explore the aperture through touch and sight, and to contemplate the text, opening it to new meaning. A full catalog of textual and tactile interactive parchment holes awaits, but the study and analysis of the hole in the Floreffe Bible on folio 180r provides the methodology and evidence needed to explore other similar situations. The discovery of a vulnus in the Book of Durrow demonstrates that this practice extended as early as the seventh century and, significantly, included the Gospel text itself. If this understanding of the hole on folio 180r is accurate, the Floreffe Bible provides a complex example from the twelfth century, infused with typological and exegetical richness, inviting the reader to explore the opening in the text, through not only sight but touch. 